\title{
Systems biology research at BGRS-2018
}

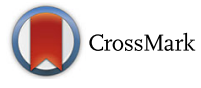

\author{
Yuriy L. Orlov ${ }^{1,2^{*}}$, Ralf Hofestädt ${ }^{3}$ and Ancha V. Baranova ${ }^{4,5}$ \\ From 11th International Multiconference "Bioinformatics of Genome Regulation and StructurelSystems Biology" - BGRSISB- \\ 2018 \\ Novosibirsk, Russia. 20-25 August 2018
}

In this Special Issue of BMC Systems Biology we present four studies representing systems biology research at BGRS $\backslash S B$ (Bioinformatics of Genome Regulation and Structure $\backslash$ Systems Biology) - 2018 multi-conference (http://conf.bionet.nsc.ru/bgrssb2018/en/). This biannual meeting is conducted in Academgorodok, Novosibirsk since 1998. Other special issues of the BGRS conference series include manuscripts in the fields of plant biology, genomics, bioinformatics and genetics, and collated as BMC Genomics, BMC Evolutionary Biology, BMC Neuroscience, BMC Genetics, BMC Medical Genomics and BMC Plant Biology supplements in recent years [1-4]. We would also like to bring attention of the reader to the highlight of the genetics and bioinformatics research at Belyaev Readings-2017 (http://conf.bionet.nsc.ru/belyaev100/en), which was held in 2017, in BioMed Central journals [5-8].

The papers below were presented in the frames of BGRS $\backslash S B$-affiliated symposium "Systems Computational Biology" (http://conf.bionet.nsc.ru/bgrssb2018/en/englishsystems-computational-biology/) and at 10th International Young Scientists School (SBB-2018) (http://conf.bionet.nsc. ru/bgrssb2018/en/school/).

Dmitry Sakharov and coauthors [9] performed comprehensive comparison of Caco-2 monolayers grown in traditional 2D culture and in a microfluidic chip. It turns out that cultivation conditions influence the spectrum of specific miRNA, secreted by Caco- 2 cells substantially. Moreover, these two types of culture display differences in their cell adhesion molecules. This work is an addition to a recent series of papers $[10,11]$ which describe various steps toward the development of a multi-tissue organson-a-chip device.

Alexey Moskalev and co-authors [12] dissected a role of unpaired 1 gene in ageing of D. melanogaster by overexpressing it various organs of the fly. In addition to its

\footnotetext{
* Correspondence: orlov@bionet.nsc.ru

${ }^{1}$ Institute of Cytology and Genetics SB RAS, 630090 Novosibirsk, Russia

${ }^{2}$ Novosibirsk State University, 630090 Novosibirsk, Russia

Full list of author information is available at the end of the article
}

pronounced and sex-specific effects on a lifespan, overexpressing of upd1 led to an increase in mRNA levels of the JAK/STAT target genes, pointing that pharmacological modulation of this pathway may eventually help to counteract ageing.

Lyudmila Pastushkova and her colleagues [13] endeavor to perform the study of urine proteome to discover biomarkers of adaptation. Notably, they showed that urine proteome profiles correctly sort individuals into cohorts with one or another predominant type of autonomic regulation of the heart rate. Functional analysis of identified protein biomarkers highlighted many molecules contributing to vascular rigidity. Interested reader should also peruse the previous studies published by the same group, which also investigated the changes in urine proteome detected after spaceflight $[14,15]$.

Ulyana Zubairova and co-authors [16] developed an ImageJ-plugin for the processing of multi-frame multichannel 3D images obtained from confocal laser scanning microscopy. This plug-in was extensively tested in high-throughput analysis of cereal leaf epidermis architecture, thus being instrumental for the development of the spatial model for this important plant tissue.

Many authors of the four manuscripts described above are young scientists working on their Master or $\mathrm{PhD}$ Dissertation in Biology, Biotechnology or related fields. BioMed Central previously had published special issues comprised of materials prepared by participants of International Young Scientists Schools "Systems Biology and Bioinformatics" (SBB) held in Novosibirsk, Russia (http://conf.bionet.nsc.ru/sbb2018/en/). We invite our readers worldwide to attend our next events - Systems Biology and Bioinformatics Young Scientists School SBB-2019 which will be held in Novosibirsk (http://conf.bionet.nsc.ru/sbb2019/en/), and Vavilov Society Congress - 2019 in St. Petersburg, Russia, in summer 2019. Systems biology field will be highlighted at VII Congress of Vavilov Society of Geneticists and Breeders organized 
by of Saint Petersburg State University 18-22 June 2019 (https://events.spbu.ru/events/genetic-selection-2019).

\section{Acknowledgements}

We are grateful to Professors N.A. Kolchanov, A.V. Kochetov, H.V. Westerhoff and $\mathrm{M}$. Barberis, for organization of the multi-conference and providing platform for international bioinformatics research, and to Institute of Cytology and Genetics SB RAS (budget project 0324-2019-0040) and Novosibirsk State University (Russian Ministry of Education and Science Project No.28.12487.2018/12.1) for hosting the conference and logistics support. The BGRSISB-2018 conference organization and systems biology session were supported by the Russian Foundation of Basic Research, Russian-German and Sino-Russian Virtual Bioinformatics Network.

The quest editors of the special issue are grateful to the conference committee members and reviewers who helped in the articles editing and issue preparation: Matteo Barberis (University of Amsterdam, Netherlands), Ming Chen (Zhejiang University, China), Taras Pasternak (Albert Ludwigs University, Germany), Udo Schumacher (Institute of Anatomy and Experimental Morphology, Germany), Tatiana Tatarinova (University of La Verne, CA, USA), Rex Palmer (Birkbeck University of London, UK), Andrey Turchinovich (German Cancer Research Center, Heidelberg, Germany), Andrey Gorchakov (Institute of Molecular and Cellular Biology SB RAS, Russia), Igor Chernyavsky (University of Manchester, UK), Ekaterina Ilgisonis (Institute of Biomedical Chemistry, Moscow, Russia), Marat Bogdanov (Institute of Genetics, Ufa, Russia), Vadim Nimaev (Institute of Lymphology, Novosibirsk, Russia).

\section{Funding}

Publication of this article was not covered by sponsorship.

\section{About this supplement}

This article has been published as part of BMC Systems Biology Volume 13 Supplement 1, 2019: Selected articles from BGRSISB-2018: systems biology. The full contents of the supplement are available online at https:// bmcsystbiol.biomedcentral.com/articles/supplements/volume-13supplement-1.

\section{Authors' contributions}

$A B$ and $Y O$ are guest editors of the special post-conference issues and Program Committee members of BGRSISB-2018 conference. RH is Chairman of the conference. All the authors read, revised and approved the final manuscript.

\section{Ethics approval and consent to participate}

Not applicable.

\section{Consent for publication}

Not applicable.

\section{Competing interests}

The authors declare that they have no competing interests.

\section{Publisher's Note}

Springer Nature remains neutral with regard to jurisdictional claims in published maps and institutional affiliations.

\section{Author details \\ ${ }^{1}$ Institute of Cytology and Genetics SB RAS, 630090 Novosibirsk, Russia. ${ }^{2}$ Novosibirsk State University, 630090 Novosibirsk, Russia. ${ }^{3}$ Bielefeld University, 33615 Bielefeld, Germany. ${ }^{4}$ School of Systems Biology, George Mason University, Fairfax, VA, USA. ${ }^{5}$ Research Centre for Medical Genetics, Moscow 115478, Russia.}

Published: 5 March 2019

\section{References}

1. Orlov YL, Baranova AV, Hofestadt R, Kolchanov NA. Computational genomics at BGRSISB-2016: introductory note. BMC Genomics. 2016;17(Suppl 14):996.

2. Orlov YL, Baranova AV, Salina EA. Computational plant bioscience at BGRSISB-2016: introductory note. BMC Plant Biol. 2016;16(Suppl 3):243.
3. Orlov YL, Baranova AV, Markel AL. Computational models in genetics at BGRSISB-2016: introductory note. BMC Genet. 2016;17(Suppl 3):155.

4. Orlov YL, Baranova AV, Kolchanov NA, Moroz LL. Evolutionary biology research at BGRS-2018. BMC Evol Biol. 2019;19(Suppl 1). https://doi.org/10. 1186/s12862-019-1368-5

5. Orlov YL, Fernandez-Masso JR, Chen M, Baranova AV. Medical genomics at Belyaev Conference - 2017. BMC Med Genomics. 2018;11(Suppl 1):11.

6. Orlov YL, Moroz LL, Baranova AV. Neuroscience researches at Belyaev conference-2017. BMC Neurosci. 2018:19(Suppl 1):14.

7. Orlov YL, Baranova AV, Tatarinova TV, Kolchanov NA. Genetics at Belyaev conference - 2017: introductory note. BMC Genet. 2017:18(Suppl 1):116.

8. Orlov YL, Baranova AV, Chen M, Salina EA. Plant biology at Belyaev conference - 2017. BMC Plant Biol. 2017:17(Suppl 2):257.

9. Sakharov DA, Maltseva DV, Knyazev EN, Nikulin SV, Poloznikov AA, Shilin SA, Baranova A, Tsypina IM, Tonevitsky AG. Towards embedding Caco-2 model of gut interface 2 in a microfluidic device to enable multi-organ models for systems biology. BMC Syst Biol. 2019;13(Suppl 1). https://doi.org/10.1186/ s12918-019-0686-y.

10. Materne EM, Ramme AP, Terrasso AP, Serra M, Alves PM, Brito C, Sakharov DA, Tonevitsky AG, Lauster R, Marx U. A multi-organ chip co-culture of neurospheres and liver equivalents for long-term substance testing. J Biotechnol. 2015;205:36-46.

11. Poloznikov A, Gazaryan I, Shkurnikov M, Nikulin S, Drapkina O, Baranova A, Tonevitsky A. In vitro and in silico liver models: current trends, challenges and opportunities. ALTEX. 2018:35(3):397-412.

12. Moskalev A, Proshkina E, Zhavoronkov A, Shaposhnikov M. Effects of unpaired 1 gene overexpression on the lifespan of Drosophila melanogaster. BMC Syst Biol. 2019;13(Suppl 1). https://doi.org/10.1186/s12918-019-0687-x.

13. Pastushkova LH, Rusanov VB, Goncharova AG, Brzhozovskiy AG, Kononikhin AS, Chernikova AG, Kashirina DN, Nosovsky AM, Baevsky RM, Nikolaev EN, Larina IM. Urine proteome changes associated with autonomic regulation of heart rate in cosmonauts. BMC Systems Biol. 2019; 13(Suppl 1). https://doi.org/10.1186/s12918-019-0688-9.

14. Brzhozovskiy A, Kononikhin A, Indeykina M, Pastushkova L, Popov IA, Nikolaev EN, Larina IM. Label-free study of cosmonaut's urinary proteome changes after long-duration spaceflights. Eur J Mass Spectrom (Chichester). 2017;23(4):225-9.

15. Kononikhin AS, Starodubtseva NL, Pastushkova LK, Kashirina DN, Fedorchenko KY, Brhozovsky AG, Popov IA, Larina IM, Nikolaev EN. Spaceflight induced changes in the human proteome. Expert Rev Proteomics. 2017:14(1):15-29.

16. Zubairova US, Verman PY, Oshchepkova PA, Elsukova AS, Doroshklov AV. LSM$W^{2}$ : laser scanning microscopy worker for wheat leaf surface morphology. BMC Systems Biol. 2019;13(Suppl 1). https://doi.org/10.1186/s12918-019-0689-8.

\section{Ready to submit your research? Choose BMC and benefit from:}

- fast, convenient online submission

- thorough peer review by experienced researchers in your field

- rapid publication on acceptance

- support for research data, including large and complex data types

- gold Open Access which fosters wider collaboration and increased citations

- maximum visibility for your research: over $100 \mathrm{M}$ website views per year

At BMC, research is always in progress.

Learn more biomedcentral.com/submissions 